\title{
Association between metabolic syndrome and quality of life
}

\author{
Associação entre síndrome metabólica e qualidade de vida
}

\author{
Patrícia Pozas Saboya ${ }^{1,2,3} \bowtie$, Luiz Carlos Bodanese ${ }^{1,2,3}$, Paulo Roberto Zimmermann ${ }^{2,4}$, Andreia da Silva Gustavo ${ }^{3,6}$, \\ Fabrício Edler Macagnan ${ }^{5}$, Ana Maria Pandolfo Feoli ${ }^{3,6}$, Margareth da Silva Oliveira ${ }^{3,7}$, Fernanda Lourega Chieza ${ }^{3}$ \\ Service of Cardiology, Hospital São Lucas, Pontifícia Universidade Católica do Rio Grande do Sul. Porto Alegre, Rio Grande do Sul, Brazil. \\ ${ }^{2}$ School of Medicine, Pontifícia Universidade Católica do Rio Grande do Sul. Porto Alegre, Rio Grande do Sul, Brazil. \\ Research Group MERC (Modificação do Estilo de Vida e Risco Cardiovascular: Modification of Lifestyle and Cardiovascular Risk). \\ Pontifícia Universidade Católica do Rio Grande do Sul. Porto Alegre, Rio Grande do Sul, Brazil. \\ ${ }^{4}$ Service of Psychiatry, Hospital São Lucas, Pontifícia Universidade Católica do Rio Grande do Sul. Porto Alegre, Rio Grande do Sul, Brazil. \\ ${ }^{5}$ Faculty of Nursing, Nutrition and Psysiotherapy, Pontifícia Universidade Católica do Rio Grande do Sul. Porto Alegre, Rio Grande do Sul, Brazil. \\ ${ }^{6}$ Faculty of Physiotherapy, Universidade Federal de Ciências da Saúde de Porto Alegre. Porto Alegre, Rio Grande do Sul, Brazil. \\ ${ }^{7}$ School of Humanities, Psychology Course, Pontifícia Universidade Católica do Rio Grande do Sul. Porto Alegre, Rio Grande do Sul, Brazil.
}

\section{ABSTRACT}

Aims: Despite all progress made in understanding and treating metabolic syndrome, the study of its impact on quality of life is still controversial and not well understood. The aim of this study was to test the hypothesis that metabolic syndrome can be associated with a worse quality of life. Methods: A controlled cross-sectional study included individuals with metabolic syndrome, from the sub-analysis of a randomized clinical trial about lifestyle modification and cardiovascular risk factors, as well as individuals with no metabolic syndrome, attended as outpatients in several clinics at a general university hospital in Southern Brazil. Measurements were made in individual interviews and included data collection, laboratory tests, and application of general scales such as Mini-Mental State Examination and Medical Outcomes Study Short Form, General Health Survey (SF-36). Comparisons of quantitative data used the Student's t test, followed by analysis of covariance or multiple linear regression for adjustment, and correlation coefficient. For categorical data, the Chi-square or Fisher's exact test were used.

Results: The study included 229 individuals, 118 metabolic syndrome and 111 no metabolic syndrome. In univariate analysis, metabolic syndrome was significantly associated with lower scores in the social functioning $(p<0.001)$ and role emotional $(p=0.019)$ quality of life domains, and with the Mental Component Summary score of the SF-36 ( $\mathrm{p}=0.013$ ). However, after adjustments for confounding factors, especially body mass index, the significance of these associations was lost. The only significant association between metabolic syndrome and quality of life that has remained after the adjustments was with worse QOL in the role emotional domain, but only in men ( $p=0.049$ ).

Conclusions: After adjusting for multiple variables, metabolic syndrome was significantly associated with decreased quality of life scores in men in the role emotional domain.

KEY WORDS: metabolic syndrome X; risk factors; quality of life.

\section{RESUMO}

Objetivos: Apesar dos avanços no entendimento e tratamento da síndrome metabólica, o estudo do seu impacto sobre a qualidade de vida é ainda controverso e inconclusivo. O objetivo deste estudo foi testar a hipótese de que a síndrome metabólica estaria associada à piora da qualidade de vida.

Métodos: Um estudo transversal controlado incluiu indivíduos com síndrome metabólica, advindos da subanálise de um estudo controlado randomizado sobre modificação de estilo de vida e fatores de risco cardiovascular; e indivíduos sem síndrome metabólica, provenientes de diversos ambulatórios de um hospital geral no sul do Brasil. As medidas foram realizadas em entrevistas individuais, que incluíram coleta de dados demográficos, testes laboratoriais e aplicação do Exame do Estado Mental e o Medical Outcome Study Short Form, General Health Survey (SF-36). Para comparações entre dados quantitativos, foram utilizados teste t de Student, análise de covariância ou regressão linear múltipla para os ajustes dos fatores confundidores, e coeficiente de correlação. Para dados categóricos foi utilizado o qui quadrado ou o Exato de Fisher quando necessário.

Resultados: O estudo incluiu 229 indivíduos, sendo 118 com síndrome metabólica e 111 sem síndrome metabólica. A síndrome metabólica foi significativamente associada com baixos escores de qualidade de vida nos domínios funcionamento $\operatorname{social}(p<0,001)$ e aspectos emocionais $(\mathrm{p}=0,019)$; e com baixos escores no Componente Sumário da Saúde Mental do SF-36 ( $\mathrm{p}=0,013)$. Entretanto, após ajustes para os fatores confundidores, especialmente índice de massa corporal, a significância dessas associações foi perdida. A única associação significativa que foi mantida entre síndrome metabólica e qualidade de vida após a análise ajustada foi com o domínio aspectos emocionais, embora somente em homens $(\mathrm{p}=0,049)$.

Conclusões: Após o ajuste para múltiplas variáveis, a síndrome metabólica foi significativamente associada com diminuição da pontuação para qualidade de vida em homens, no domínio aspectos emocionais.

DESCRITORES: síndrome X metabólica; fatores de risco; qualidade de vida. 
Abbreviations: MS, metabolic syndrome; QOL, quality of life; SF-36, Medical Outcomes Study Short Form, General Health Survey; BMI, body mass index; $\mathrm{CoG}$, Control group; $\mathrm{CaG}$, Case group; WC, waist circumference; SBP, systolic blood pressure; DBP, diastolic blood pressure; TGL, triglycerides; HDL-c, high density lipoprotein cholesterol; PCS, physical component summary; MCS, mental component summary; PUCRS, Pontifícia Universidade Católica do Rio Grande do Sul.

\section{INTRODUCTION}

Metabolic syndrome (MetS), as a complex set of cardiovascular risk factors related to abdominal fat and resistance to insulin, is strongly associated with high cardiovascular morbimortality [1-3]. The incidence of MetS has been increasing progressively, and it has an estimated global prevalence of up to $23.7 \%$ according to Adult Treatment Panel III [4].

Most of the studies examining the association between MetS and quality of life (QOL) found significant association between MetS and impaired QOL [5-27]. However, eight of them mentioned significant association only in women [16-23], and three of them were exclusively composed of female samples [21-23]. Some studies stated that this association only remained significant when MetS was also associated with depression [26] or higher body mass index (BMI) [27].

Similarly, data from controlled randomized studies also confirm this association, revealing improvement in the MetS components, followed by better QOL scores after interventions to change lifestyle [28-37], in up to 24 months of follow-up [28]. Cohort studies assessing association between MetS and QOL corroborate these data, even though analyzing data in a different way. On one hand, low QOL scores, besides being associated with MetS, were predictors for mortality in a 5-year follow-up [38]. On the other hand, psychosocial wellbeing was inversely predictive of MetS in a 4.5-year follow-up [39].

Only one study did not find association between MetS and impaired QOL after adjustments for confounding factors [40]. Unfortunately, there are still little evidence and problems concerning a low proportion of longitudinal studies and a different health-related quality of life instruments, that have contributed to the lack of evidence.

Relationship between MetS and QOL, despite its relevance and treatment possibilities, has been receiving little attention in medical literature. Thus, the aim of this study was to investigate the association between MetS and QOL in the population of a developing country, in order to better understand this situation and develop a new approach that includes a change in lifestyle for those who suffer from MetS. We hypothesized that MetS would be associated with the worsening of QOL.

\section{METHODS}

\section{Participants}

This cross sectional controlled study was conducted at the outpatient service and the rehabilitation center of a university general hospital in Southern Brazil. It was an arm of a major randomized clinical trial about lifestyle modification and cardiovascular risk factors involved in metabolic syndrome. The clinical trial included male and female, with or without MetS. The project was approved by the Ethics Board from Pontifícia Universidade Católica do Rio Grande do Sul (PUCRS) under the number 10/05153.

For this study, the sample included individuals aged 30-59 years. For the Case Group $(\mathrm{CaG})$, individuals met MetS criteria: waist circumference (WC) $>88 \mathrm{~cm}$ for women and $>102 \mathrm{~cm}$ for men, in the presence of two or more criteria; systolic blood pressure (SBP) $\geq 130 \mathrm{mmHg}$ and diastolic blood pressure (DBP) $\geq 85$ $\mathrm{mmHg}$; fasting glucose $\geq 100 \mathrm{mg} / \mathrm{dl}$; triglycerides (TGL) $\geq 150 \mathrm{mg} / \mathrm{dl}$; high density lipoprotein cholesterol (HDL-c) $<40 \mathrm{mg} / \mathrm{dl}$ for men and $<50 \mathrm{mg} / \mathrm{dl}$ for women or for those under medication use [1-3]. CaG was consecutively selected from September 2010 to April 2013.

Control Group (CoG) outpatients came from a previous study, consecutively selected in the period between December 2007 and December 2008. The methodology used for obtaining their clinical and demographic data was previously published [41]. To be included in the CoG, subjects were between 30-59 years old, did not have MetS, performed the SF-36, and had available information about socio-demographic data.

Exclusion criteria for both groups included significant cognitive impairment (utilizing the cutoff point below 19 in the Mini-Mental State Examination [42] scores), diagnosis of severe psychiatric disorders, acute myocardial infarction or a history of coronary artery disease (as confirmed by exercise stress testing, myocardial scintillography and/ or catheterization), and uncontrolled thyroid disorder. Regarding the CoG, those who had a diagnosis of diabetes mellitus were also excluded, as to avoid possible biases. 
In order to join the study, individuals signed a written informed consent previously approved by the Ethics Board. After signing the informed consent, the patients who agreed to participate in the study were subjected to individual interviews, conducted by the researchers or monitors, who were submitted to quality standard training for data collection.

\section{Data collection}

Demographic data were collected by means of a structured questionnaire devised by the researchers, which was applied individually. The questionnaire contained basic identification data, health data such as diagnosis, medication in use, smoking, alcohol use and physical activity. Intake of alcohol was considered for male up to $1 \mathrm{oz}(30 \mathrm{ml})$ of ethanol/day, and for female $0.5 \mathrm{oz}(15 \mathrm{ml})$ of ethanol/day [43]. Presence of physical activity was considered for the individuals that practiced regular exercises at least once a week, as opposed to the ones who did not exercise, who were classified as sedentary [43-44]. MetS was diagnosed as described in the inclusion criteria.

Anthropometric profile included weight and height for the calculation of BMI and WC. The participants were barefoot and lightly dressed. Weight was checked with an electronic scale $\left(\right.$ Cauduro $^{\circledR}$, Cachoeira do Sul, Brazil) properly calibrated. Height was measured by vertical anthropometer (Sunny ${ }^{\circledR}$, Fortaleza, Brazil). WC measurement was taken as described by Lohman et al (1988) [45], using a non-extensible anthropometric tape. SBP and DBP were taken in three consecutive measures according to the American [43] and European [46] Hypertension Guidelines.

Blood samples were collected after overnight fasting. To analyze fasting glucose, TGL, total cholesterol, and HDL-c, standard enzymatic methods used reagents in a fully automated analyzer (Vitros 950 dry chemistry system; Johnson \& Johnson, Rochester, NY, USA), and low density lipoprotein cholesterol was estimated using the Friedewald equation [47]. Plasma and serum were stored at $-80^{\circ} \mathrm{C}$ for later analyses at the laboratory of Sao Lucas Hospital, from PUCRS.

QOL was measured using the Medical Outcomes Study Short Form, General Health Survey (SF-36). It consists of a scale of 36 questions that evaluate the QOL of individuals in relation to their disease. It is divided into eight areas which describe the physical functioning, limitations due to physical problem, bodily pain, general health perceptions, vitality, social functioning, role limitations due to emotional problems, and mental health. These areas were summarized into Physical Component Summary (PCS) and Mental Component Summary (MCS). The scores range from 0 to 100 for each domain, in which higher scores indicate better QOL [48].

\section{Statistical analysis}

Quantitative data were described by mean and standard deviation. In the presence of asymmetry, the median and interquartile ranges (25th percentile to 75 th percentile) were used. Categorical variables were presented by counts and percentages. Comparisons between quantitative data used the $t$ test, followed by analysis of covariance or multiple linear regression for adjustment, and correlation coefficient. For categorical data, Chi-square or Fisher's exact test were used. The results were subjected to statistical analysis using the software IBM SPSS Statistics V21, with an alpha level of significance of $5 \%$.

\section{RESULTS}

At all, 229 individuals were selected for the study, 118 for $\mathrm{CaG}$ and 111 for CoG. Most of them were female, 116 (71.9\%) and white, 199 (86.9\%). The groups showed similar distribution regarding race, physical activity and use of alcohol. There was significantly statistical difference regarding age, gender, marital status and especially educational level, once most subjects in the $\mathrm{CaG}$ group had over nine years of education. These and other sociodemographic variables are shown in Table 1.

Considering the eight domains assessed by the SF-36, there was no significant difference between the two groups regarding the mean scores for QOL. While the $\mathrm{CaG}$ had an overall SF-36 score of 113.75 the $\mathrm{CoG}$ had a score of 116.62. Considering the calculations of the PCS and MCS, subjects with MetS scored significantly lower only in the MCS score, although there was no statistically significant difference after adjustment for confounding factors (Table 2).

Considering each domain individually, the $\mathrm{CaG}$ showed average above $50 \%$, even though it had lower scores than the $\mathrm{CoG}$ in most domains. The only domains that had better scores in the $\mathrm{CaG}$ were general health and bodily pain, although none of them presented statistical significance. The domain with the lowest mean scores in the $\mathrm{CaG}$ was vitality, although there was no significant statistical difference when compared to the mean scores in the CoG. However, social functioning and role emotional had 
Table 1. Univariate analysis of sociodemographic characteristics, anthropometric data, and lifestyle habits of participants with metabolic syndrome (Case Group) and without metabolic syndrome (Control Group). Porto Alegre, RS, Brazil, $2007-2013$.

\begin{tabular}{|c|c|c|c|c|}
\hline Characteristics & $\begin{array}{c}\text { Total sample } \\
(n=229)\end{array}$ & $\begin{array}{l}\text { Case Group } \\
(n=118)\end{array}$ & $\begin{array}{l}\text { Control Group } \\
\quad(n=111)\end{array}$ & $\mathbf{p}$ \\
\hline Age, years (mean \pm SD) & $47.8 \pm 8.3$ & $49.9 \pm 7.7$ & $45.6 \pm 8.4$ & $<0.001^{*}$ \\
\hline Female, no (\%) & $167(72.9)$ & $72(61.0)$ & 95 (85.6) & $<0.001^{+}$ \\
\hline White, no (\%) & $199(88.4)$ & $102(89.5)$ & $97(87.4)$ & $0.68^{+}$ \\
\hline \multicolumn{5}{|l|}{ Marital Status, n (\%) } \\
\hline With companion & $148(67.3)$ & $73(67.0)$ & $75(67.6)$ & \multirow{3}{*}{$0.021^{+}$} \\
\hline Single & $62(28.2)$ & $27(24.8)$ & 35 (31.5) & \\
\hline Widowed & $10(4.5)$ & $9(8.3)$ & $1(0.9)$ & \\
\hline \multicolumn{5}{|l|}{ Level of education, n (\%) } \\
\hline 4 years of study & $28(12.2)$ & $1(0.8)$ & $27(24.3)$ & \multirow{3}{*}{$<0.001^{\dagger}$} \\
\hline 5 to 8 years of study & $53(23.1)$ & $6(5.1)$ & $47(42.3)$ & \\
\hline Over 9 years of study & $148(64.6)$ & $111(94.1)$ & $37(33.3)$ & \\
\hline Body mass index, $\mathrm{kg} / \mathrm{m}^{2}($ mean $\pm \mathrm{SD})$ & $30.8 \pm 5.2$ & $34.4 \pm 3.6$ & $27.1 \pm 3.7$ & $<0.001^{*}$ \\
\hline Body mass index $\geq 30$ kg/m2 (obese) & $124(54.1)$ & $104(88.1)$ & $20(18.0)$ & $<0.001^{+}$ \\
\hline Sedentariness, $\mathrm{n}(\%)$ & $161(70.6)$ & $79(67.5)$ & $82(73.9)$ & $0.31^{+}$ \\
\hline Smoking, n (\%) & $30(13.2)$ & $6(5.2)$ & $24(21.6)$ & $<0.001^{\dagger}$ \\
\hline Use of alcohol, n (\%) & $6(2.6)$ & $5(4.3)$ & $1(0.9)$ & $0.21^{\dagger}$ \\
\hline
\end{tabular}

SD, standard deviation. ${ }^{*}$ Student's t test. ${ }^{+}$Chi-square.

significant association with MetS $(\mathrm{p}<0.001$ and 0.019 , respectively), although the physical functioning had borderline significance. The variable with the stronger association with QOL was social functioning, once MetS was associated with a fall of 13 points in the SF-36, with mean scores of 77.6 in the $\mathrm{CaG}$ and 90.9 in the $\mathrm{CoG}$ (although the mean scores were not considered low). Nevertheless, after adjustments for confounding factors such as BMI, gender, educational level, sedentary lifestyle, use of alcohol and smoking, the statistical significance of these associations was lost (Table 3).
Table 2. Clinical measures for participants with metabolic syndrome (Case Group) and without metabolic syndrome (Control Group). Porto Alegre, RS, Brazil, 2007-2013.

\begin{tabular}{lcccc}
\hline Characteristics & $\begin{array}{c}\text { Case Group } \\
(\mathbf{n}=\mathbf{1 1 8})\end{array}$ & $\begin{array}{c}\text { Control Group } \\
(\mathbf{n}=\mathbf{1 1 1})\end{array}$ & $\mathbf{p}$ & $\begin{array}{c}\text { Adjusted } \\
\mathbf{p}^{*}\end{array}$ \\
\hline SF-36 & $113.7 \pm 16.5$ & $116.6 \pm 19.3$ & $0.229^{+}$ & 0.367 \\
PCS & $47.6 \pm 7.4$ & $46.9 \pm 9.4$ & $0.562^{+}$ & 0.153 \\
MCS & $47.4 \pm 11.6$ & $51.1 \pm 11.1$ & $0.013^{+}$ & 0.152 \\
\hline
\end{tabular}

* ANCOVA = Analysis of Covariance with adjustment for BMI, sex, level of education, age, sedentary lifestyle, smoking and alcohol use. + t test.

Data presented as mean \pm standard deviation.

SF-36, Medical Outcome Study Short Form, General Health Survey; PCS, Physical component summary; MCS, Mental component summary.

Table 3. Means for the Score of the SF-36 in participants with metabolic syndrome (Case Group) and without metabolic syndrome (Control Group). Porto Alegre, RS, Brazil, 2007-2013.

\begin{tabular}{|c|c|c|c|c|c|c|c|c|c|c|c|c|}
\hline Variable & $\begin{array}{c}\text { Case } \\
\text { Group } \\
\mathbf{n = 1 1 8}\end{array}$ & $\begin{array}{c}\text { Control } \\
\text { Group } \\
n=111\end{array}$ & p & $\begin{array}{c}\text { Case } \\
\text { Group } \\
\mathrm{n}=118\end{array}$ & $\begin{array}{c}\text { Control } \\
\text { Group } \\
n=111\end{array}$ & P* & $\begin{array}{c}\text { Case } \\
\text { Group } \\
\mathbf{n}=118\end{array}$ & $\begin{array}{c}\text { Control } \\
\text { Group } \\
n=111\end{array}$ & $\mathbf{p}^{\dagger}$ & $\begin{array}{c}\text { Case } \\
\text { Group } \\
\mathrm{n}=118\end{array}$ & $\begin{array}{l}\text { Control } \\
\text { Group } \\
n=111\end{array}$ & $\mathbf{p}^{\ddagger}$ \\
\hline $\begin{array}{l}\text { Physical } \\
\text { functioning }\end{array}$ & $76.1 \pm 1.7$ & $81.0 \pm 1.9$ & 0.056 & $79.7 \pm 2.1$ & $77.3 \pm 2.2$ & 0.490 & $78.8 \pm 3.0$ & $79.9 \pm 2.4$ & 0.790 & $80.9 \pm 4.9$ & $79.2 \pm 4.5$ & 0.683 \\
\hline Role-physical & $77.6 \pm 2.9$ & $81.5 \pm 3.5$ & 0.388 & $80.1 \pm 3.9$ & $78.8 \pm 4.0$ & 0.841 & $74.6 \pm 5.5$ & $78.2 \pm 4.4$ & 0.631 & $75.7 \pm 9.3$ & $75.9 \pm 8.6$ & 0.986 \\
\hline Bodily pain & $64.3 \pm 2.2$ & $58.7 \pm 2.6$ & 0.094 & $66.6 \pm 2.8$ & $56.3 \pm 3.0$ & 0.030 & $65.9 \pm 4.0$ & $59.3 \pm 3.2$ & 0.228 & $72.6 \pm 6.9$ & $64.6 \pm 6.4$ & 0.173 \\
\hline $\begin{array}{l}\text { General } \\
\text { Health }\end{array}$ & $69.0 \pm 1.7$ & $66.3 \pm 2.3$ & 0.346 & $72.7 \pm 2.4$ & $62.4 \pm 2.5$ & 0.011 & $70.5 \pm 3.4$ & $63.5 \pm 2.8$ & 0.132 & $69.0 \pm 5.8$ & $65.4 \pm 5.4$ & 0.454 \\
\hline Vitality & $59.0 \pm 2.0$ & $63.8 \pm 2.1$ & 0.100 & $62.2 \pm 2.4$ & $60.4 \pm 2.5$ & 0.668 & $62.8 \pm 3.5$ & $61.7 \pm 2.8$ & 0.826 & $65.3 \pm 5.9$ & $67.2 \pm 5.4$ & 0.706 \\
\hline $\begin{array}{l}\text { Social } \\
\text { functioning }\end{array}$ & $77.6 \pm 2.1$ & $90.9 \pm 2.2$ & $<0.001$ & $80.9 \pm 2.6$ & $87.4 \pm 2.7$ & 0.128 & $81.4 \pm 3.7$ & $88.9 \pm 2.9$ & 0.135 & $86.0 \pm 6.1$ & $94.6 \pm 5.7$ & 0.102 \\
\hline $\begin{array}{l}\text { Role } \\
\text { emotional }\end{array}$ & $69.5 \pm 3.4$ & $81.1 \pm 3.6$ & 0.019 & $72.3 \pm 4.2$ & $78.1 \pm 4.3$ & 0.405 & $71.4 \pm 5.9$ & $79.5 \pm 4.8$ & 0.316 & $78.1 \pm 10.1$ & $90.2 \pm 9.3$ & 0.161 \\
\hline Mental health & $68.9 \pm 1.8$ & $70.6 \pm 2.1$ & 0.532 & $71.2 \pm 2.3$ & $68.1 \pm 2.4$ & 0.420 & $72.6 \pm 3.3$ & $70.3 \pm 2.6$ & 0.605 & $75.0 \pm 5.5$ & $76.3 \pm 5.1$ & 0.780 \\
\hline
\end{tabular}

* ANCOVA: Analysis of Covariance with adjustment in 3 models: p*: body mass index (BMI); p $^{+}$: BMI, sex, level of education; p $^{\ddagger}$ : Full Adjusted: BMI, sex, level of education, age, sedentary lifestyle, smoking and alcohol use.

Data presented as mean \pm standard error. SF-36: Medical Outcome Study Short Form, General Health Survey. 
BMI had a significant association with components of Physical Health, as well as with components of Mental Health in the QOL domains, once individuals with higher BMI had worse QOL, lowering the mean scores of SF-36 in up to three points (Table 3).

When compared the QOL mean scores between men and women, women with or without MetS obtained lower scores in all domains of QOL, except for the role physical domain. For male, although there was significant association between MetS and physical and social functioning domains in the univariate analysis, only the role emotional domain showed significant association with MetS after adjustments for confounding factors. For females, despite significant association of role emotional and social functioning domains with MetS, the significance was lost after adjustments for confounding factors (Table 4).

The analysis of the number of components of MetS (three, four and five) related to the SF-36 scores did not find significant association, even after logistic regression, although there was a slight reduction in the mean scores with the increase in the number of MetS criteria. Concerning the impact of the MetS components over the QOL domains, only TGL and HDL presented correlation with some of the SF-36 domains. While there was correlation between higher TGL scores and worse scores in the physical functioning, vitality and role emotional domains, higher HDL scores showed correlation with worse scores in bodily pain. Both correlations, however, were weak. (Table 5).

Table 4. Mean difference for the score of the SF-36 in participants with metabolic syndrome (Case Group) and without metabolic syndrome (Control Group), stratified by gender. Porto Alegre, RS, Brazil, 2007-2013.

\begin{tabular}{|c|c|c|c|c|c|c|}
\hline \multirow{2}{*}{ Variable } & Mean difference & \multirow{2}{*}{$\mathbf{p}$} & \multirow{2}{*}{ Adjusted $\mathrm{p}^{*}$} & Mean difference & \multirow{2}{*}{ p } & \multirow{2}{*}{ Adjusted $\mathrm{p}^{*}$} \\
\hline & Men & & & Women & & \\
\hline Physical functioning & $13.0(6.0 ; 20.1)$ & 0.001 & 0.059 & $5.1(1.0 ; 11.2)$ & 0.104 & 0.236 \\
\hline Role-physical & $2.5(18.5 ; 23.6)$ & 0.807 & 0.964 & $4.0(6.9 ; 14.9)$ & 0.467 & 0.966 \\
\hline Bodily pain & $0.3(14.9 ; 15.5)$ & 0.971 & 0.781 & $4.5(12.2 ; 3.2)$ & 0.251 & 0.188 \\
\hline General health & $2.1(16.1 ; 11.6)$ & 0.763 & 0.783 & $1.7(8.3 ; 4.9)$ & 0.604 & 0.511 \\
\hline Vitality & $10.3(2.3 ; 22.8)$ & 0.103 & 0.230 & $4.3(2.3 ; 11.0)$ & 0.199 & 0.957 \\
\hline Social functioning & $17.9(7.5 ; 28.3)$ & 0.001 & 0.215 & $12.9(5.6 ; 20.2)$ & 0.001 & 0.233 \\
\hline Role emotional & $15.1(5.9 ; 36.1)$ & 0.151 & 0.049 & $11.4(0.1 ; 22.8)$ & 0.051 & 0.340 \\
\hline Mental health & $6.1(4.8 ; 17.0)$ & 0.264 & 0.295 & $2.4(3.8 ; 8.6)$ & 0.447 & 0.920 \\
\hline
\end{tabular}

* ANCOVA: Analysis of Covariance with adjustment for body mass index, sex, level of education, age, sedentary lifestyle, smoking and alcohol use.

Data presented as mean difference $\pm 95 \%$ confidence interval of the difference. SF-36: Medical Outcome Study Short Form, General Health Survey.

Table 5. Correlation between SF-36 domains and the components of metabolic syndrome in non-adjusted and adjusted analysis by multiple linear regression. Participants with metabolic syndrome (Case Group). Porto Alegre, RS, Brazil, $2007-2013$.

\begin{tabular}{|c|c|c|c|c|c|c|c|c|c|c|c|c|c|}
\hline Variable & & WC & $\mathbf{p}$ & TGL & p & HDL-c & p & FG & p & SBP & p & DBP & p \\
\hline \multirow{2}{*}{ Physical functioning } & $r$ & 0.041 & 0.792 & -0.206 & 0.037 & 0.060 & 0.941 & -0.014 & 0.929 & 0.028 & 0.812 & 0.006 & 0.901 \\
\hline & $r^{a}$ & 0.025 & & -0.198 & & 0.007 & & 0.008 & & 0.023 & & 0.012 & \\
\hline \multirow{2}{*}{ Role-physical } & r & 0.059 & 0.590 & -0.118 & 0.284 & -0.024 & 0.556 & -0.135 & 0.207 & -0.094 & 0.712 & -0.102 & 0.689 \\
\hline & $r^{a}$ & 0.052 & & -0.103 & & -0.057 & & -0.121 & & -0.035 & & -0.038 & \\
\hline \multirow{2}{*}{ Bodily pain } & r & -0.130 & 0.070 & -0.045 & 0.262 & -0.152 & 0.028 & -0.072 & 0.472 & 0.042 & 0.173 & -0.028 & 0.270 \\
\hline & $r^{a}$ & -0.172 & & -0.107 & & -0.207 & & -0.069 & & 0.130 & & -0.105 & \\
\hline \multirow{2}{*}{ General health } & $r$ & -0.102 & 0.190 & -0.141 & 0.093 & -0.072 & 0.156 & -0.187 & 0.063 & -0.093 & 0.788 & -0.083 & 0.788 \\
\hline & $r^{\mathrm{a}}$ & -0.125 & & -0.160 & & -0.135 & & -0.176 & & -0.026 & & -0.026 & \\
\hline \multirow{2}{*}{ Vitality } & $r$ & -0.036 & 0.554 & -0.197 & 0.040 & 0.022 & 0.539 & -0.021 & 0.994 & -0.035 & 0.633 & -0.091 & 0.426 \\
\hline & $r^{a}$ & -0.056 & & -0.195 & & -0.059 & & 0.001 & & 0.046 & & -0.076 & \\
\hline \multirow{2}{*}{ Social functioning } & $r$ & -0.037 & 0.755 & -0.107 & 0.400 & 0.088 & 0.608 & 0.083 & 0.358 & -0.076 & 0.873 & -0.100 & 0.606 \\
\hline & $r^{a}$ & -0.030 & & -0.081 & & 0.049 & & 0.088 & & -0.015 & & -0.050 & \\
\hline \multirow{2}{*}{ Role emotional } & r & -0.100 & 0.186 & -0.194 & 0.033 & 0.023 & 0.487 & -0.021 & 0.984 & 0.000 & 0.452 & -0.058 & 0.474 \\
\hline & $r^{a}$ & -0.126 & & -0.202 & & -0.066 & & -0.002 & & 0.072 & & -0.068 & \\
\hline \multirow{2}{*}{ Mental health } & $r$ & -0.115 & 0.162 & -0.123 & 0.203 & 0.047 & 0.788 & 0.089 & 0.273 & -0.020 & 0.235 & -0.131 & 0.096 \\
\hline & $\mathrm{r}^{\mathrm{a}}$ & -0.133 & & -0.121 & & -0.026 & & 0.104 & & 0.113 & & -0.158 & \\
\hline
\end{tabular}

r: Correlation coefficient; $r^{\text {a }}$ Partial correlation coefficient

Correlation: 0.0-0.1 - trivial; 0.1-0.3 - low; 0.3-0.5 - moderate; 0.5-0.7 - high; 0.7-0.9 - very large; 0.9-1.0 - nearly perfect. (Hopkins, 1997)

SF-36: Medical Outcome Study Short Form, General Health Survey; WC, waist circumference; TGL, triglycerides; HDL-c, high-density lipoprotein-cholesterol; FG, fasting glucose; SBP, systolic blood pressure; DBP, diastolic blood pressure. 


\section{DISCUSSION}

This study tested the hypothesis of an association between MetS and worse QOL, investigating a sample of individuals with and without MetS seen at a tertiary hospital. Results indicated that after adjustments for confounding factors, MetS was not significantly associated with decrease on QOL when considered the whole sample with both genders, which does not fully confirm the hypothesis previously established. However, presence of MetS was associated with worse QOL in the role emotional in men.

Regarding sociodemographic data, although there was a significant difference between the groups related to age, between the range of 45-49 years old, this finding does not seem to have clinical relevance, because the variation found in the age range does not present major physiological difference in the subject's functioning. For this reason, they are classified within the same age range, according to World Health Organization [49].

However, the difference between the groups regarding educational level might have contributed to the smaller difference found between QOL mean scores in the groups studied. This may occurs because low educational level is also associated with worse QOL scores [50]. CoG could have lower QOL scores due to the low level of education.

Although there was association between MetS and worse QOL in some of the SF-36 domains in the univariate analysis, this association was lost after being adjusted for confounding factors. These findings confront the results of most studies, which support the idea that MetS would be significantly associated with worse QOL [5-13,15], even though they corroborate the findings of some studies $[26,27,40]$ which did not find significant association between MetS and QOL after adjustments for confounding factors. It is noteworthy that different QOL assessment instruments had been used in those studies. As shown in other studies, MCS was also associated with QOL $[6,16]$, although in this study the significant association was lost after adjustments [16]. The higher scores found in the general health and bodily pain domains in the CoG may be related to the fact that this group sample is composed of subjects attending an outpatient service during data collection, which might have increased scores.

Regarding BMI, there was a significant difference between subjects with or without MetS. According to results obtained in previous studies [6,10,26,27,51], higher BMI was significantly associated with lower QOL scores in most SF-36 scores, and with lower
PCS scores. Nevertheless, the present study found association not only with lower PCS scores, but also with lower MCS scores of SF-36.

Considering the association between BMI and QOL scores, and in attempt to understand the possible reasons for the loss of significance, the SF-36 scores were adjusted in three different models for confounding factors. The presence of BMI, adjusted separately in model 1, had a significant impact in the QOL domains, once the significance of the associations found were lost after adjusted. This means that the association between MetS and worsening QOL would be explained by the increase in BMI and not by MetS, reinforcing the idea that there is association between higher BMI and worse health-related QOL in the general population $[52,53]$.

When the sample was stratified by gender, unlike the findings of association between MetS and worse QOL in women [16-23], this study did not find this association after being adjusted for confounding factors. Yet, as shown in other studies $[18,19]$ when comparing the mean scores between the genders, women with or without MetS showed lower QOL scores in most SF-36 domains. On the other hand, there was significant association in men, even after adjustments, between the role emotional domain and QOL, as well as in previous studies [6,19], although this association was not kept in one of these studies [19], possibly due to the fact that a different adjustment model had been used.

Gender differences in the association between MetS and QOL are not conclusive, although most of the available studies found significant association in women. It was surprising that in this study the association between MetS and QOL was found just in men. Maybe this finding occurred by chance due to the small sample size and should be confirmed in futures studies. On the other hand, the association between MetS and role emotional domain can be explained and corroborated by the already know association of MetS with depression and anxiety [26,54-57], because this domain analyze role limitations due to emotional problems.

The fact that there was no significant association between increase in the number of MetS components and decrease in QOL scores might be explained also by the small sample size, which was not able to demonstrate this effect unlike previous studies $[5,7,16,17]$. Concerning the impact of MetS components on QOL, the available evidence shows association between low HDL-c levels $[12,15,40]$, high BP levels $[10,12,17,40]$, high TGL $[12,40]$, high levels of fasting plasma glucose $[5,10,12]$ and low QOL scores. The correlation 
of increased HDL-c with worse scores in the bodily pain domain challenges the evidence [15], but might be due to the use of medication for cholesterol, such as statins, which could be overestimating HDL-c levels, even not reaching the desired protective effect, besides causing myalgia as a side effect.

Considering that there was no significant statistic difference in most SF-36 domains when comparing subjects of both genders with or without MetS, this study indicated that the health status and QOL in MetS subjects did not suffer significant negative impact of MetS itself. The QOL scores of subjects in this sample were above $50 \%$, which suggests that both groups presented good overall life conditions and/or adjustment to the disease. It is important to highlight that some studies that found significant association between MetS and QOL also disclosed mean scores above $50 \%$ in 8 SF-36 domains $[6,16,27]$.

The fact that this study did not demonstrate significant negative impact of MetS on QOL in both genders draws attention, since MetS might not initially impair QOL. At first, it is only a set of silent risk factors for cardiovascular disease, and for this reason, the search for treatment and its adhesion might be compromised, because treatment strategies involve a change in lifestyle which must be perceived and desired by the patient. On the other hand, the fact that the study found a significant association between MetS and decreased QOL scores in the role emotion domain, in men, highlights the importance of screening for anxiety and depression in MetS individuals.

This study has some limitations. First of all, as a cross-sectional study, it was not able to establish a causal link of the associations. Secondly, the fact that the $\mathrm{CoG}$ was formed by outpatients in a general hospital could have influenced the perceived health status, causing biased results, although subjects were selected based on disease-free criteria. Moreover, considering the fact that many associations have disappeared with the logistic regression, the sample size was a limitation of this study.

In summary, this study provides preliminary data that MetS has a significant association with men's worse QOL, in terms of role emotional. However, since there are few studies in this area and data are still controversial and non-conclusive, further studies are necessary to definitely confirm this association and, therefore, contribute to devise more effective preventive and therapeutic measures in order to reduce the prevalence of this major health problem.

\section{NOTES}

\section{Financial support}

This study was financially supported by a grant from the Brazilian National Council of Scientific and Technological Development (CNPq), number 481279/2009.

Conflicts of interest disclosure

The authors declare no potential conflicts of interest relevant to the content of this study.

\section{REFERENCES}

1. Executive summary of the third report of the National Cholesterol Education Program (NCEP) expert panel on detection, evaluation, and treatment of high blood cholesterol in adults (Adult Treatment Panel III). JAMA. 2001;285:2486-97. http://dx.doi.org/10.1001/ jama.285.19.2486

2. Alberti G,Zimmet P,Shaw J, Grundy SM. The IDF consensus worldwide definition of the metabolic syndrome. International Diabetes Federation, 2006.

3. Diretriz Brasileira para diagnóstico e tratamento da síndrome metabólica. Hipertensão. 2004;7(4):121-63.

4. Ford ES, Giles WH, Dietz WH. Prevalence of the metabolic syndrome among US adults: findings from the third National Health and Nutrition Examination Survey. JAMA. 2002;16;287(3):356-9.

5. Roohafza H, Sadeghi M, Talaei M, Pourmoghaddas Z, Sarrafzadegan N. Psychological status and quality of life in relation to the metabolic syndrome: Isfahan cohort study. Int J Endocrinol. 2012;2012:380902. http://dx.doi.org/10.1155/2012/380902

6. Tziallas D, Kastanioti C, Kostapanos MS, Skapinakis P, Elisaf MS, Mavreas V. The impact of the metabolic syndrome on health-related quality of life: a cross-sectional study in Greece. Eur J Cardiovasc Nurs. 2012;11(3):297-303.

7. Katano S, Nakamura Y, Nakamura A, Suzukamo Y, Murakami Y, Tanaka T, Okayama A, Miura K, Okamura T, Fukuhara S, Ueshima H. Relatioship between health-related quality of life and clustering of metabolic syndrome diagnostic components. Qual Life Res. 2012;21(7):1165-70. http://dx.doi.org/10.1007/s11136-011-0029-y 
8. Ford ES, Li C. Metabolic syndrome and health-related quality of life among U.S. adults. Ann Epidemiol. 2008;18(3):165-71. http://dx.doi. org/10.1016/j.annepidem.2007.10.009

9. Han JH, Park HS, Shin CI, Chang HM, Yun KE, Cho SH, Choi EY, Lee SY, Kim JH, Sung HN, Kim JH, Choi SI, Yoon YS, Lee ES, Song HR, Bae SC. Metabolic syndrome and quality of life (QOL) using generalised and obesity-specific QOL scales. Int J Clin Pract. 2009;63(5):735-41. http://dx.doi.org/10.1111/j.1742-1241.2009.02021.x

10. Corica F, Corsonello A, Apolone G, Mannucci E, Lucchetti M, Bonfiglio C, Melchionda N, Marchesini G, QUOVADIS Study Group. Metabolic Syndrome, psychological status and quality of life in obesity: the QUOVADIS Study. Int J Obes (Lond). 2008;32(1):185-91. http://dx.doi.org/10.1038/sj.ijo.0803687

11. Miettola J, Niskanen LK, Viinamäki H, Sintonen H, Kumpusalo E. Metabolic syndrome is associated with impaired health-related quality of life: Lapinlahti 2005 study. Qual Life Res. 2008;17(8):1055-62. http://dx.doi.org/10.1007/s11136-008-9386-6

12. Pinar T, Pinar G, Dogan N. The presence of metabolic syndrome and associated quality of life in Turkish women with cardiovascular disease. Acta Medica. 2012;1:1-10.

13. Tekdemir EY, Karadag B, Ozcelik B, Ozturk AO, Karamustafalioglu O, Altuntas Y. Metabolic syndrome and health-related quality of life among Turkish adults. Abstracts of the 7th Metabolic Syndrome Symposium. Abstract 470. Obesity Reviews. 2010;11(6):467-88. http://dx.doi.org/10.1111/j.1467-789X.2010.00771.x

14. Huang CY, Chi SC, Sousa VD, Wang CP, Pan KC. Depression, coronary artery disease, type 2 diabetes, metabolic syndrome and quality of life in Taiwanese adults from a cardiovascular department of a major hospital in Southern Taiwan. J Clin Nurs. 2011;20(9-10): 1293-302. http://dx.doi.org/10.1111/j.1365-2702.2010.03451.x

15. Roriz-Cruz M, Rosset I, Wada T, Sakagami T, Ishine M, Roriz-Filho JS, Cruz TR, Rodrigues RP, Resmini I, Sudoh S, Wakatsuki Y, Nakagawa M, Souza AC, Kita T, Matsubayashi K. Stroke-independent association between metabolic syndrome and functional dependence, depression, and low quality of life in elderly community-dwelling Brazilian people. J Am Geriatr Soc. 2007;55(3):374-82. http://dx.doi. org/10.1111/j.1532-5415.2007.01068.x

16. Amiri P, Hosseinpanah F, Rambod M, Montazeri A, Azizi F. Metabolic syndrome predicts poor health-related quality of life in women but not in men: Tehran Lipid and Glucose Study. J Womens Health (Larchmt). 2010;19(6):1201-7 http://dx.doi.org/10.1089/jwh.2009.1710

17. Park SS, Yoon YS, Oh SW. Health-related quality of life in metabolic syndrome: the Korea National Health and Nutricion Examination Survey 2005. Diabetes Res Clin Pract. 2011;91(3):381-8. http://dx.doi.org/10.1016/j.diabres.2010.11.010

18. Sohn YJ, Sohn HS, Kwon JW. Gender differences among middle-aged Koreans for Health-related quality of life related to metabolic syndrome. Qual Life Res. 2011;20(4):583-92. http://dx.doi.org/10.1007/s11136-010-9789-z

19. Frisman GH, Kristenson M. Psychosocial status and health related quality of life in relation to the metabolic syndrome in a Swedish middle-aged population. Eur J Cardiovasc Nurs. 2009;8(3):207-15. http://dx.doi.org/10.1016/j.ejcnurse.2009.01.004

20. Sarrafzadegan N, Gharipour M, Ramezani MA, Rabiei K, Zolfaghar B, Tavassoli AA, Boshtam M, Zarfeshani S, Khosravi A, Yousefi A. Metabolic syndrome and health-related quality of life in Iranian population. J Res Med Sci. 2011;16(3):254-61.

21. Hjellset VT, Ihlebæk CM, Bjorge B, Eriksen HR, Hostmark AT. Health-related quality of life, subjective health complaints, psychological distress and coping in Pakistani immigrant women with and without the metabolic syndrome: The InnvaDiab-DEPLAN Study on Pakistani Immigrant Women Living in Oslo, Norway. J Immigr Minor Health. 2011;13(4):732-41. http://dx.doi.org/10.1007/s10903-010-9409-6

22. Qader SS, Shakir YA, Samsioe G. Could quality of life impact the prevalence of metabolic syndrome? Results from a population-based study of Swedish women: the Women's Health in the Lund Area Study. Metab Syndr Relat Disord. 2008;6(3):203-7. http://dx.doi. org/10.1089/met.2008.0014

23. Lidfeldt J, Nyberg P, Nerbrand C, Samsioe G, Scherstén B, Agardh CD. Socio-demographic and psychosocial factors are associated with features of the metabolic syndrome. The Women's Health in the Lund Area (WHILA) study. Diabetes Obes Metab. 2003;5(2):106-12. http://dx.doi.org/10.1046/j.1463-1326.2003.00250.x

24. Okosun IS, Annor F, Esuneh F, Okoegwale EE. Metabolic syndrome and impaired health-related quality of life and in non-Hispanic white, non-Hispanic blacks and Mexican-American adults. Diabetes Metab Syndr. 2013;7(3):154-60. http://dx.doi.org/10.1016/j.dsx.2013.06.007

25. Rouch I, Achour-Crawford E, Roche F, Castro-Lionard C, Laurent B, Ntougou Assoumou G, et al. Seven-year predictors of self-rated health and life satisfaction in the elderly: the PROOF study. J Nutr Health Aging. 2014;18(9):840-7. http://dx.doi.org/10.1007/s12603-014-0557-6

26. Vetter ML, Wadden TA, Lavenberg J, Moore RH, Volger S, Perez JL, Sarwer DB, Tsai AG. Relation of health-related quality of life to metabolic syndrome, obesity, depression and comorbid illnesses. Int J Obes (Lond). 2011;35(8):1087-94. http://dx.doi.org/10.1038/ ijo. 2010.230

27. Tsai AG, Wadden TA, Sarwer DB, Berkowitz RI, Womble LG, Hesson LA, Phelan S, Rothman R. Metabolic syndrome and health-related quality of life in obese individuals seeking weigh reduction. Obesity (Silver Spring). 2008;16(1):59-63. http://dx.doi.org/10.1038/oby.2007.8

28. Bischoff SC, Damms-Machado A, Betz C, Herpertz S, Legenbauer T, Löw T, Wechsler JG,Bischoff G, Austel A, Ellrott T. Multicenter evaluation of an interdisciplinary 52-week weight loss program for obesity with regard to body weight, comorbidities and quality of life - a prospective study. Int J Obes (Lond). 2012;36(4):614-24. http://dx.doi.org/10.1038/ijo.2011.107

29. Sarwer DB, Moore RH, Diewald LK, Chittams J, Berkowitz RI, Vetter M, Volger S, Wadden TA for the POWER-UP Research Group. The impact of a primary care-based weight loss intervention on quality of life. Int J Obes (Lond). 2013;37(01):S25-30. http://dx.doi org/10.1038/ijo.2013.93 
30. Kalter-Lebovici O, Younis-Zeidan N, Atamna A, Lubin F, Alpert G, Chetrit A, Novikov I, Daoud N, Freedman LS. Lifestyle intervention in obese Arab women: a randomized controlled Trial. Arch Intern Med. 2010;170(11):970-6. http://dx.doi.org/10.1001/archinternmed.2010.103

31. Cezaretto A. Intervenção interdisciplinar para prevenção de diabetes mellitus sob a perspectiva da psicologia: benefícios na qualidade de vida. [Dissertação]. [São Paulo]: Universidade de São Paulo; 2010.

32. Eriksson KM, Westborg CJ, Eliasson MC. A randomized trial of lifestyle intervention in primary healthcare for the modification of cardiovascular risk factors. Scand J Public Health. 2006;34(5):453-61. http://dx.doi.org/10.1080/14034940500489826

33. Levinger I, Goodman C, Hare DL, Jerums G, Selig S. The effect of resistance training on functional capacity and quality of life in individuals with high and low numbers of metabolic risk factors. Diabetes Care. 2007;30(9):2205-10. http://dx.doi.org/10.2337/dc07-0841

34. Landaeta-Díaz L, Landaeta-Díaz L, Fernández JM, Da Silva-Grigoletto M, Rosado-Alvarez D, Gómez-Gardu-o A et al. Mediterranean diet, moderate-to-high intensity training, and health-related quality of life in adults with metabolic syndrome. Eur J Prev Cardiol. 2013;20(4):555-64. http://dx.doi.org/10.1177/2047487312445000

35. Madero M, Arriaga JC, Jalal D, Rivard C, McFann K, Pérez-Méndez O, Vázquez A, Ruiz A, Lanaspa MA, Jimenez CR, Johnson RJ, Lozada LG. The effect of two energy-restricted diets, a low-fructose diet versus a moderate natural fructose diet, on weight loss and metabolic syndrome parameters: a randomized controlled trial. Metabolism. 2011;60(11):1551-9. http://dx.doi.org/10.1016/j.metabol.2011.04.001

36. Kanaya AM, Araneta MR, Pawlowsky SB, Barrett-Connor E, Grady D, Vittinghoff E, Schembri M, Chang A, Carrion-Petersen ML, Coggins T, Tanori D, Armas JM, Cole RJ. Restorative yoga and metabolic risk factors: the Practicing Restorative Yoga vs. Stretching for the Metabolic Syndrome (PRYSMS) randomized trial. J Diabetes Complications. 2014;28(3):406-12. http://dx.doi.org/10.1016/j. jdiacomp.2013.12.001

37. Stuckey MI, Gill DP, Petrella RJ. Does systolic blood pressure response to lifestyle intervention indicate metabolic risk and health-related quality-of-life improvement over 1 year? J Clin Hypertens (Greenwich). 2015;17(5):375-80. http://dx.doi.org/10.1111/jch.12531

38. Zhang JP, Pozuelo L, Brennan DM, Hoar B, Hoogwerf BJ. Association of SF-36 with coronary artery disease risk factors and mortality: a PreCIS study. Prev Cardiol. 2010;13(3):122-9.

39. Daniel M, Paquet C, Coffee N, Howard N, Cargo M, Taylor A, Hugo G, Adams R. Metabolic syndrome incidence in a population-based, representative biomedical cohort over 4.5 years: assessing area-level socioeconomic disadvantage and individual psychosocial wellbeing. Abstracts of the 4th International Congress on Prediabetes and the Metabolic Syndrome. J Diabetes. 2011;3 Suppl.1:11. http://dx.doi. $\operatorname{org} / 10.1111 / j .1753-0407.2011 .00122 . x$

40. Lee YJ, Woo SY, Ahn JH, Cho S, Kim SR. Health-Related Quality of Life in Adults with Metabolic Syndrome: The Korea National Health and Nutrition Examination Survey, 2007-2008. Ann Nutr Metab. 2012;61:275-80. http://dx.doi.org/10.1159/000341494

41. Saboya PM, Zimmermann PR, Bodanese LC. Association between anxiety or depressive symptoms and arterial hypertension, and their impact on the quality of life. Int J Psychiatry Med. 2010;40(3):307-20. http://dx.doi.org/10.2190/PM.40.3.f

42. Bertolucci PH, Brucki, SM, Campacci SR, Juliano Y. O mini-exame do estado mental em uma população geral: impacto da escolaridade. Arq Neuro-Psiquiatr. 1994;52(1):1-7. http://dx.doi.org/10.1590/S0004-282X1994000100001

43. Chobanian AV, Bakris GL, Black HR, Cushman WC, Green LA, Izzo JL, Jones DW, Materson BJ, Oparil S, Wright JT Jr, Roccella EJ, National Heart, Lung, and Blood Institute Joint National Committee on Prevention, Detection, Evaluation, and Treatment of High Blood Pressure; National High Blood Pressure Education Program Coordinating Committee. The Seventh Report of the Joint National Committee on Prevention, Detection, Evaluation, and Treatment of High Blood Pressure: the JNC 7 report. JAMA. 2003;289:2560-72. http://dx.doi. org/10.1001/jama.289.19.2560

44. Lee IM, Rexrode KM, Cook NR, Manson JE, Buring JE. Physical activity and coronary heart disease in women: Is "no pain, no gain" passe? JAMA. 2001;285:1447-54. http://dx.doi.org/10.1001/jama.285.11.1447

45. Lohman TG, Roche AF, Martorell R. Anthropometric Standardization Reference Manual. Champaign, Il: Human Kinetics Books; 1988.

46. Mancia G, De Backer G, Dominiczak A, Cifkova R, Fagard R, Germano G, Grassi G, Heagerty AM, Kjeldsen SE, Laurent S, Narkiewicz K, Ruilope L, Rynkiewicz A, Schmieder RE, Struijker Boudier HA, Zanchetti A, Vahanian A, Camm J, De Caterina R, Dean V, Dickstein K, Filippatos G, Funck-Brentano C, Hellemans I, Kristensen SD, McGregor K, Sechtem U, Silber S, Tendera M, Widimsky P, Zamorano JL, Kjeldsen SE, Erdine S, Narkiewicz K, Kiowski W, Agabiti-Rosei E, Ambrosioni E, Cifkova R, Dominiczak A, Fagard R, Heagerty AM, Laurent S, Lindholm LH, Mancia G, Manolis A, Nilsson PM, Redon J, Schmieder RE, Struijker-Boudier HA, Viigimaa M, Filippatos G, Adamopoulos S, Agabiti-Rosei E, Ambrosioni E, Bertomeu V, Clement D, Erdine S, Farsang C, Gaita D, Kiowski W, Lip G, Mallion JM, Manolis AJ, Nilsson PM, O’Brien E, Ponikowski P, Redon J, Ruschitzka F, Tamargo J, van Zwieten P, Viigimaa M, Waeber B, Williams B, Zamorano JL, The task force for the management of arterial hypertension of the European Society of Hypertension, The task force for the management of arterial hypertension of the European Society of Cardiology. 2007 Guidelines for the management of arterial hypertension: The Task Force for the Management of Arterial Hypertension of the European Society of Hypertension (ESH) and of the European Society of Cardiology (ESC). Eur Heart J. 2007;28:1462-536. http://dx.doi.org/10.1097/hjh.0b013e3281 fc975a

47. Friedewald WT, Levy RI, Fredrickson DS. Estimation of the concentration of low-density lipoprotein cholesterol in plasma, without use of the preparative ultracentrifuge. Clin Chem. 1972;18(6):499-502.

48. Ciconelli RM, Ferraz MB, Santos W, Meinão I, Quaresma MR. Tradução para a língua portuguesa e validação do questionário genérico de avaliação de qualidade de vida SF-36 (Brasil SF-36). Rev Bras Reumatol. 1999;39:143-50.

49. United Nations. Department of Economic and Social Affairs. Provisional Guidelines on Standard International Age Classifications. United Nations: New York; 1982. 
50. Sprangers MA, de Regt EB, Andries F, Van Agt HM, Bijl RV, de Boer JB, Foets M, Hoeymans N, Jacobs AE, Kempen GI, Miedema HS, Tijhuis MA, de Haes HC. Which chronic conditions are associated with better or poorer quality of life? J Clin Epidemiol. 2000;53(9): 895-907. http://dx.doi.org/10.1016/S0895-4356(00)00204-3

51. Jia H, Lubetkin EI. The impact of obesity on health-related quality-of-life in the general adult U.S. population. J Public Health. 2005;27: 156-64. http://dx.doi.org/10.1093/pubmed/fdi025

52. Søltoft F, Hammer M, Kragh N. The association of body mass index and health-related quality of life in the general population: data from the 2003 Health Survey of England. Qual Life Res. 2009;18(10):1293-9. http://dx.doi.org/10.1007/s11136-009-9541-8

53. Ford ES, Moriarty DG, Zack MM, Mokdad AH, Chapman DP. Self-reported body mass index and health-related quality of life: Findings from the Behavioral Risk Factor Surveillance System. Obes Res. 2001;9:21-31. http://dx.doi.org/10.1038/oby.2001.4

54. Nishina M., Nishina K., Ohira T., Makino K., Iso H. Associations of psychological distress with metabolic syndrome among Japanese urban residents. J Atheroscler Thromb. 2011;18(5):396-402. http://dx.doi.org/10.5551/jat.6692

55. Van Reedt Dortland A.K., Giltay E.J., Van Veen T., Zitman F.G., Penninx B.W. Metabolic syndrome abnormalities are associated with severity of anxiety and depression and with tricyclic antidepressant use. Acta Psychiatr Scand. 2010;122(1):30-9. http://dx.doi.org/10.1111/ j.1600-0447.2010.01565.x

56. Luppino FS, van Reedt Dortland AK, Wardenaar KJ, Bouvy PF, Giltay EJ, Zitman FG, Penninx BW. Symptom dimensions of depression and anxiety and the metabolic syndrome. Psychosom Med. 2011;73(3):257-64. http://dx.doi.org/10.1097/PSY.0b013e31820a59c0

57. Carroll D, Phillips AC, Thomas GN, Gale CR, Deary I, Batty GD. Generalized anxiety disorder is associated with metabolic syndrome in the Vietnam experience study. Biol Psychiatry. 2009;66(1):91-3. http://dx.doi.org/10.1016/j.biopsych.2009.02.020 